\title{
Nuestros amigos los residentes
}

\author{
About residents of surgery
}

Una de las principales dificultades que tienen nuestros residentes de cirugía es, sin duda, el problema económico. Aunque parezca increible, ellos también necesitan alimentarse, pagar arriendo y servicios básicos como luz, agua, gas, teléfono, etc. Sumado a esto está la falta de tiempo suficiente para el estudio, para el descanso o para compartir con su familia, frecuentemente el tiempo dedicado al trabajo se lo quita al hogar. El estilo de vida de un cirujano joven y de un residente de cirugía es muy complejo ya que es difícil proyectarse para el futuro y organizar su vida, porque que su periodo de especialización suele ser la época laboral más conflictiva y coincide con la época de formar una familia.

La cirugía ha cambiado muchísimo en los últimos años y es muy frecuente que los cirujanos en formación se inclinen por una determinada subespecialidad a partir del primer año de su programa de especialización. Entonces, ¿qué va a ocurrir con el cirujano general? La pregunta carece una clara respuesta, pese a que es probable que los cirujanos deban trabajar, una vez completada la etapa formativa guiada, en hospitales pequeños o medianos de provincia.

Durante su formación, hay aspectos fundamentales que se deben evaluar en el residente: sus conocimientos teóricos, sus habilidades o destrezas y su personalidad o actitudes. Se debe precisar y evaluar permanentemente cuáles son sus actitudes más destacadas, su calidad humana, su afabilidad, generosidad, espiritu de colaboración con los demás. Es muy importante que aprenda a estar en contacto permanente con el paciente y su familia. Pero también es importante que aprenda a enseñar, es decir a transmitir a los alumnos de pregrado, internos y a residentes de niveles inferiores los conocimientos y enseñanzas que él ha ido aprendiendo y profundizando.

El residente quirúrgico debe aprender, comprender y desarrollar las dos cualidades principales e indispensables del buen cirujano, es decir, destreza o habilidad operatoria y, lejos lo más importante, buen juicio y criterio quirúrgico, lo que debe aplicarse también al período preoperatorio y al manejo postoperatorio.

Los residentes son habitualmente el nexo más importante entre el paciente y su familia; su importante e imprescindible colaboración no siempre es bien comprendida ni correspondida, a pesar que soportan en su diaria labor una carga importante del trabajo asistencial dentro de un Servicio de Cirugía o de un Servicio de Urgencia. Por este motivo debemos procurar tenerles un lugar digno para el descanso en estas unidades para que estén en buenas condiciones para asumir sus funciones con la debida calidad y responsabilidad.

Pero esta responsabilidad debe ser progresiva y siempre supervisada, evitando la "explotación", tanto por parte de los cirujanos formadores como de los que ocupan puestos directivos dentro de un Servicio o Departamento. La frase: ¡todos hemos sido becados! es muy recurrente en nuestro medio y se emplea para justificar la sobredosis de trabajo o responsabilidad que se le asigna al cirujano en formación. Es conocido el hecho que los cirujanos que laboran en los Servicios de Urgencia de los hospitales públicos reclaman porque no tienen becados en su turno, o no los tienen en el número que ellos consideran suficiente, y no siempre es para sobrecargarlos de docencia.

Unos consejos para nuestros amigos y colegas en formación:

El teléfono celular es una herramienta de trabajo de gran importancia pero NUNCA se debe tener encendido en el pabellón de operaciones. Las razones son múltiples y obvias. Desgraciadamente este mal hábito (que yo personalmente no comparto) es frecuente en muchos cirujanos y anestesiólogos. Además deben ser extremadamente cuidadosos al expresar sus opiniones, o emitir comentarios descalificadores, jevitar ese "gran sentido del rumor"! tan frecuente y tan desarrollado en nuestro medio y, especialmente, en el ámbito 
de la cirugía. Este defecto, muy condenable, se da con gran frecuencia en los cirujanos más jóvenes pero los años y la experiencia van paliando en alguna medida este mal hábito.

Los residentes no son culpables de TODAS las complicaciones ni eventos indeseables que puedan ocurrir en la evolución postoperatoria de algún enfermo, ni tienen ningún tipo de relación comercial con virus, hongos o bacterias. Por supuesto que, como todos nosotros, pueden tener o no algún grado de responsabilidad en algunos aspectos y en algunas ocasiones. Estas complicaciones, como es lógico, pueden minimizarse con una adecuada enseñanza y supervisión adecuada y constante.

La enseñanzas y consejos serán mejor entendidos, comprendidos, captados, adquiridos y practicados, si inicialmente se hizo una buena selección de candidatos al ingreso al programa. Debemos enseñarles, en primer lugar, a ser responsables y disciplinados, a tener buen criterio quirúrgico, o sea, que aprendan a tomar las decisiones adecuadas antes, durante y después de la intervención quirúrgica, lo que implica un buen diagnóstico preoperatorio. Además deben conocer muy bien las técnica quirúrgicas para cada caso y manejarse con habilidad durante la intervención. Obviamente en este buen criterio quirúrgico está incluido el saber cómo prevenir complicaciones o, al menos, saber tomar las medidas adecuadas para minimizar el riesgo.

Es indispensable que nosotros les demos a ellos el ejemplo de responsabilidad y disciplina en el manejo diario de nuestros pacientes, de honestidad y humildad con nosotros mismos y con ellos, y de compasión y comprensión para con los pacientes. De esto se trata la ética. Y sin ética no hay buen comportamiento.

Albert Schweitzer decía: "El ejemplo no es el mejor método de enseñanza, sino que es el único".

Rimsky Álvarez $U$.

Director del Departamento de Cirugía Universidad de Concepción

Concepción, Chile 